\title{
Federal-Provincial Relations and Conservatism in the Canadian West
}

\section{Connor Molineaux - University of Calgary}

Regionalism has been a prominent feature of Western Canadian political culture even prior to Alberta and Saskatchewan joining confederation in 1905. One manifestation of this regionalism is through intergovernmental conflict, particularly jurisdictional disputes between the provincial and federal governments. These disputes have generally seen provincial governments of various ideological leanings cooperate, and yet decentralizationor expansion of provincial jurisdiction-is a position that has largely been advanced by conservatives in recent decade. ${ }^{1}$ Is there an ideological connection between expansion of provincial jurisdiction and conservatism? This essay contends that the conservative ideology particular to Western Canada was uniquely influenced by the dynamic of federal-provincial relations in Canada because of particular features of the region's brand of conservatism. This essay will demonstrate that ongoing disputes between western provinces-Alberta in particular-and the federal government, particularly over natural resource issues, have reinforced a dynamic of regionalism within Western Canadian conservatism, leading it to become the perennial feature of conservative policy, federally and provincially, that it is today.

\section{Early Conflict and Exploitation}

The roots of conflict between the West and Ottawa can be traced back to the territorial government of the present-day western provinces prior to 1905. Despite entering a period of settlement and growth, the Northwest Territories frequently lacked effective representation in the Dominion Government. ${ }^{2}$ Lacking the autonomy of full-fledged provinces, the Northwest Territories required the approval of the federal government for access to funding, including for vital infrastructure. Gayle Thrift suggests that as early as 1883, discontent with the treatment of the territories was brewing, with a movement underway to lobby Ottawa for increased representation and autonomy. ${ }^{3}$ Even the Dominion Lands Policy, David K. Elton

\footnotetext{
${ }^{1}$ Maxime Bernier, "Ottawa should quite intruding on provincial jurisdiction," National Post, October 13, 2010; Brooke Jeffrey, "Prime Minister Harper's Open Federalism: Promoting a Neo-Liberal Agenda?" in The Case for Centralized Federalism, ed. Gord DiGiacomo and Maryantonett Flumian, (Ottawa: University of Ottawa Press, 2010); David Laycock, "Making Sense of Reform as a Western Party," in Regionalism and Party Politics in Canada, ed. Lisa Young and Keith Archer (Oxford: Oxford University Press, 2001); Alain Nöel, "Is Decentralization Conservative? Federalism and the Contemporary Debate on the Canadian Welfare State," in Stretching the Federation: The Art of the State in Canada, ed. Robert Young (Kingston: Institute of Intergovernmental Relations, 1999).

${ }^{2}$ David K. Elton, "Alberta and the Federal Government in Historical Perspective, 1905-1977," in Society and Politics in Alberta: Research Papers, ed. Carlo Caldarola (Toronto: Methuen).

${ }^{3}$ Gayle Thrift, "'By the West, for the West': Frederick Haultain and the Struggle for Provincial Rights in Alberta," Alberta History 59 (2011): 4.
} 
argues, was a point of contention between westerners and the Dominion Government. The pattern of land distribution impaired the development of communities and added a great expense to communication. ${ }^{4}$

Even when the populated portions of the Northwest Territories were finally granted provincial status, the process was contentious. The Liberal government of Sir Wilfrid Laurier feared that another large province joining confederation could rival the power of the existing provinces. ${ }^{5}$ Perhaps to further mitigate the risk of domination by the west, the newly formed provinces of Alberta and Saskatchewan were denied the full autonomy of the other provinces. Most notably, the federal government retained ownership of crown land in the western provinces, leading J. R. Mallory to conclude that Alberta and Saskatchewan "were not provinces in the same sense as were Ontario and Quebec, but in the Roman sense". ${ }^{6}$ Though the westerners rebelled against this view, "Roman provinces" were in keeping with the original intents of western settlement. Sir John A. Macdonald's National Policy intended to settle the west in hopes of offsetting the dependence of Central Canada on American markets. ${ }^{7}$ Ottawa would continue to argue over the next decades that retention of western land ownership was necessary to pursue the western settlement policy of the Dominion Government. ${ }^{8}$

\section{A Political Culture Emerges}

By the time control of natural resources was granted to the western provinces, a considerable impact had already been made on the region's political culture. Gurston Dacks defines a political culture as "the pattern of fundamental ideas, of basic beliefs and values, by which a group of people interpret politics and decide how they will behave when faced with political choices". 9 Political culture should not be confounded with ideology, or with individuals' beliefs. Rather, political culture is the lens through which people participate in, and view, the political system. For example, a social democrat and a conservative may have radically different perspectives on the relationship between the provincial government and Ottawa, but in either case their views will have been coloured by the fundamental values of a region's culture. Dacks suggests that while political culture may lend a degree of constraint to the choices of political actors, actors will emphasize different aspects of political culture most politically advantageous to them. ${ }^{10}$ In terms of the dissemination of political culture, Dacks

${ }^{4}$ Elton, "Alberta and the Federal Government," 109.

${ }^{5}$ Ibid., 75.

${ }^{6}$ J. R. Mallory, Social Credit and the Federal Power in Canada (Toronto University of Toronto Press, 1954), 10.

${ }^{7}$ John Richards and Larry Pratt, Prairie Capitalism: Power and Influence in the New West (Toronto: McClelland and Stewart, 1979), 15.

${ }^{8}$ Ibid., 17.

${ }^{9}$ Gurston Dacks, "From Consensus to Competition: Social Democracy and Political Culture in Alberta," in Essays in Honour of Grant Notley: Socialism and Democracy in Alberta, ed. Larry Pratt (Edmonton: NeWest Press, 1986), 186187.

${ }^{10}$ Ibid. 
points to the media and schools, shared experiences, and a desire for newcomers to integrate as key methods. ${ }^{11}$ With regard to the substance of political culture, Barry Cooper highlights the importance of political myths, pointing out that "what begins as policy" may have significant and longstanding effects on the relationship of a people to politics. ${ }^{12}$

Thus, what began as a policy of exploitation of the west's resources by Central Canada, in time, came to be viewed as exploitation of the west itself. The traditional discussion of western discontent centres on "western alienation", which Roger Gibbins has defined as "a political ideology of regional discontent" that "encompasses a sense of political, economic, and to a lesser extent, cultural estrangement from the Canadian heartland". ${ }^{13}$ However, Gibbins's study of western alienation emphasizes the idea that there has been a substantial desire for "greater participation in and recognition by the national government," and also uses individual-level survey data as a means of attempting to capture political culture. ${ }^{14}$ Gibbins fails to articulate the logic of these assumptions: in principle, exploitation by the federal government seems at least as likely to draw westerners away from the federal government as toward it. For conservatives in particular, as we shall see below, circumstances would suggest a preference for Alberta to manage as many of its own affairs as possible, with minimal interference from the federal government. On the point of survey data, Cooper notes there is no reason to believe that this aspect of western culture would be captured via survey. ${ }^{15} \mathrm{On}$ the contrary, the use of such attitudinal data excludes the myths of political culture itself. ${ }^{16}$ The important point here is that perceptions of politics have an impact on politics itself; capturing only political realities through data misses an important part of the picture.

\section{Prairie Conservatism and Populism}

So far, we have seen the development of a political culture in which the mythology of exploitation by Ottawa is significant. Before we can develop these ideas further, we must examine a simultaneous development: the emergence of political ideology on the prairies. Nelson Wiseman suggests ideological variance across the prairie provinces developed largely as a function of immigration patterns. ${ }^{17}$ Saskatchewan was strongly influenced by British settlers and consequently the British labour movement, while Alberta was strongly influenced by liberal-populist ideas of the American Midwest. This special brand of Albertan

\footnotetext{
${ }^{11}$ Gurston Dacks, "From Consensus to Competition: Social Democracy and Political Culture in Alberta," in Essays in Honour of Grant Notley: Socialism and Democracy in Alberta, ed. Larry Pratt (Edmonton: NeWest Press, 1986), 186187.

${ }^{12}$ Barry Cooper, It's the Regime, Stupid!: A Report from the Cowboy West on Why Stephen Harper Matters (Toronto: Key Porter, 2009), 63.

${ }^{13}$ Roger Gibbins, Prairie Politics and Society: Regionalism in Decline (Toronto: Butterworths, 1980), 169.

${ }^{14}$ Ibid., 167.

${ }^{15}$ Cooper, It's the Regime Stupid, 120.

${ }^{16}$ Ibid.

${ }^{17}$ Nelson Wiseman, “The Pattern of Prairie Politics," in Party Politics in Canada, ed. Hugh G. Thorburn and Alan Whitehorn (Toronto: Prentice Hall, 2001).
} 
conservatism, Clark Banack argues, is at odds with the British toryism that predominated in the rest of English-speaking Canada. ${ }^{18}$ Tories tend to be more statist and hierarchically minded, whereas the American-Western conservatives discussed here tend to be more libertarian. ${ }^{19}$ Jared J. Wesley identifies particular values that were the product of American settlers: laissez-faire liberalism and a lack of deference manifesting as populism. ${ }^{20}$ Wesley also identifies western alienation as one of the values brought by American settlers. ${ }^{21}$ However, as has already been intimated, this value arrived as the result of Canadian phenomena. The interplay of the Canadian conditions with what began as American values has had interesting effects as is explored further below.

Not immediately obvious is that all of Alberta's major governing parties share elements of this same ideological tradition. ${ }^{22}$ The influence of American protestantism in particular underlay the United Farmers of Alberta (UFA), Social Credit, and even Progressive Conservative parties. ${ }^{23}$ Each of these parties had vastly different policy ideas yet were fundamentally governed by the same populist, and to some degree individualist, tradition. Despite the prominence of these values in Alberta and their near ubiquity in the province's government, they are not the only views widely held in Alberta nor in the prairies more broadly. For this reason, the values of western conservatism are best described as a western ideology rather than as a fundamental aspect of the region's political culture. By the same logic, although the American-influenced conservative tradition has been most prominent in Alberta, it is not isolated to it: the different ideological traditions of the west are unevenly distributed across the prairies. ${ }^{24}$ However, our interest here is on the conservative tradition in the West. Because this tradition has been most prominent in Alberta, Alberta must be the central focus.

One more feature of conservatism on the prairies must be mentioned: an ideological disposition towards the free market and capital enterprise. With perhaps the exception of Social Credit policy towards the banking industry, which was frequently the target of the government's policy experimentation, even Social Credit policy was firmly grounded in

\footnotetext{
${ }^{18}$ Clark Banack, "American Protestantism and the Roots of 'Populist Conservatism' in Alberta," in Conservatism in Canada, ed. James Farney and David Rayside (Toronto: University of Toronto Press, 2013), 231.

${ }^{19}$ Nelson Wiseman, "Provincial Conservatism," in Conservatism in Canada, ed. James Farney and David Rayside (Toronto: University of Toronto Press, 2013), 209.

${ }^{20}$ Jared J. Wesley, Code Politics: Campaigns and Cultures on the Canadian Prairies (Vancouver: UBC Press, 2011), 55.

${ }^{21}$ Ibid.

${ }^{22}$ I exclude the Alberta's initial Liberal government from this analysis given that they were initially appointed without standing election and held an incumbency advantage thereafter. I also exclude Alberta's current NDP government as there is currently insufficient literature.

${ }^{23}$ Banack, "American Protestantism."

${ }^{24}$ Wiseman, "The Pattern of Prairie Politics."
} 
capitalism and the free market. ${ }^{25}$ Unfortunately, given the Depression and the relatively unindustrialized nature of the western economy at this point in history, there was little in the way of capital-building opportunity. However, the free market spirit would play a significant role when circumstances ultimately changed.

We can now consider the combination of a political culture of discontent with the treatment of the west with the conservative values of liberalism and populism. For conservatives, there was an impulse towards autonomy, or the management of the west's own affairs within the provinces themselves. ${ }^{26}$ To be sure, most conservatives were still committed to national unity, and therefore also participation at the national level as Gibbins suggests. ${ }^{27}$ To this extent, the western alienation thesis may hold, but does not provide a complete picture for western conservatives. However, the west lacked leverage or indeed any significant motivation for more autonomy. Over the following decades, the push for autonomy became more significant.

\section{Natural Resources, Conservatism and Political Culture}

Natural resources, we have established, had an early and significant effect on the relationship between the territorial/provincial governments and the Dominion government. We have further seen that Gibbins's conception of western alienation does not reflect the true cultural significance the early federal-provincial dynamic had in the west. And now, we have seen that early western conservatism was strongly influenced by the ideas of populism and individualism, as imported from the United States. Furthermore, we have seen that an affinity between these values and the underlying political culture of regional discontent could result in a desire for more provincial autonomy. But was there any tangible connection, and how did it develop?

The early western economy was almost entirely based on agriculture. Alberta in particular was sparsely populated and dependent upon Central Canada for access to markets. Disputes between the UFA and Social Credit governments, even after natural resource rights were granted, primarily pertained to access to these markets and monetary policy otherwise. ${ }^{28}$ Freight rates to the east, a system of protective tariffs, and-in the eyes of William Aberhart-domination of the banking industry by Easterners, were evidence of continued domination by the elites of Central Canada. The federal-provincial conflict of this era was not the result of a view that the western governments needed more power for ideological reasons,

\footnotetext{
${ }^{25}$ Rand Dyck, Provincial Politics in Canada: Towards the Turn of the Century (Scarborough: Prentice Hall, 1996), 536.

${ }^{26}$ Wesley, Code Politics, 57.

${ }^{27}$ Roger Gibbins and Loleen Berdahl, Western Visions, Western Future: Perspectives on the West in Canada, second edition (Peterborough: Broadview, 2003), 50.

${ }^{28}$ Elton, "Alberta and the Federal Government," 111-112.
} 
but were rather a continued attempt to attain equality with the other provinces in the federation-whether the inequality was real or perceived. ${ }^{29} \mathrm{G}$. Bruce Doern and Glen Toner highlight that dissatisfaction with Ottawa's economic policy had a very real effect on westerners' perceptions of Central Canada whether or not the policies were truly discriminatory. ${ }^{30}$

The situation for the west and Alberta in particular changed dramatically with the discovery of oil at Leduc in 1947. Oil changed the dynamic of federal-provincial relations for two reasons: one, the properties of oil and gas themselves demand government regulation in order for the resources to be used effectively. ${ }^{31}$ The level of government setting the regulations therefore controls the pace of resource development. This ties into the second reason: significant amounts of revenue were at stake for the government and for the economy of the region itself. Regardless of ideological stripe, a rational government benefits from increasing its revenue-generating capacity. For conservative free-market supporters, such as those dominating Alberta, controlling the regulatory structure means controlling access to this market as well.

Federalism naturally complicates regulation of the oil industry. Although the provincial governments have ownership of provincial natural resources, certain sections of the British North America Act, 1867 (now the Constitution Act, 1867) make the division of powers more complicated. Under s. 91(2), the federal government has the power to regulate trade and commerce, and the sole power to raise money via taxation under s. 91(3). s. 91 also grants the federal government residual power to legislate on areas that have not explicitly been enumerated to either level of government. While provincial ownership of the resources means provinces can control and monetize their direct exploitation as owners, the federal government controls the trade of resources. ${ }^{32}$ This overlap of jurisdiction leaves significant room for dispute. Over the decades that followed, many disputes did occur, and in the process solidified the relationship between a decentralized federation and western conservatism.

\section{Energy and the Constitution}

The stage had effectively been set for conflict. A culture in the west, particularly for conservatives, of mistrust for the federal government had combined with a considerable turn

${ }^{29}$ The Social Credit movement was clearly 'ideological' in the sense that it had specific policy preferences it wished to pursue provincially; however, these policies were in response to supposedly discriminatory policies of the federal government. Therefore, the disputes of the Social Credit government can still rightly be included with conflicts of equality. See ibid., 113.

${ }^{30}$ G. Bruce Doern and Glen Toner, The Politics of Energy: The Development and Implementation of the NEP (Toronto: Methuen, 1985), 163.

${ }^{31}$ Richards and Pratt, Prairie Capitalism, 47.

${ }^{32}$ Robert D. Cairns, "Natural Resources and Canadian Federalism: Recurring Conflict, and Resolution," Publius: The Journal of Federalism 22 (Winter 1992): 55-70. 
of fortune in the way of economic opportunity. As such, throughout the 1970s and 1980s, we see a pattern by which each level of government tries to strengthen its jurisdictional claim. Prior to 1973, the federal and provincial governments generally agreed on the goals of energy policy: to stimulate the energy industry. ${ }^{33}$ Nonetheless, both levels of government were actively trying to increase their jurisdictional authority through new legislation.

The federal government asserted its role in regulating trade between provinces and internationally in 1949 through the creation of the Pipe Line Act. Only federally incorporated companies would be able to transport natural gas via pipeline outside of the province of production, and the routing for any pipelines would require approval of the federal government. ${ }^{34}$ The provincial government of Alberta was concerned the federal government might use this legislation to control supply and thereby change pricing in a manner most favourable for Eastern Canada. ${ }^{35}$ As we have seen, the precedent certainly existed: the resource struggles of the provinces early history show the potential for exploitation existed. In response, the Social Credit government of Ernest Manning created the Alberta Gas Trunk Line (AGTL) to carry all natural gas within the province to the provincial border. This directly undermines the federal legislation, and leaves the routing, at least to some degree, in provincial hands.

The 1973 energy shock is when conservatism became especially significant to energy jurisdiction, and provincial jurisdiction more broadly. While in the preceding decades the federal and provincial governments had largely agreed in principle, this was no longer the case. Conservatives generally, and the conservative government of Peter Lougheed, had a vision of the energy industry in which Albertans should first and foremost benefit from the industry they are directly involved in. The federal government, on the other hand, viewed the energy industry as a source of revenue and benefit for all Canadians-a policy that, in the view of Albertans, would be at their expense. ${ }^{36}$ The Albertan view emphasizes the values of individualism and populism we have identified as western conservative earlier: the ability of individual Albertans to control their own destiny. ${ }^{37}$ Moreover, the capitalist aspect of western conservatism was clearly also in play: the province emphasized the role of "local entrepreneurs" within the province, rather than the monopolistic domination of eastern interests..$^{38}$ Conservative values were the goal, but not always the means however: in order to implement this vision, the province needed to secure its jurisdictional claim. As such, Lougheed began a vigorous campaign for greater autonomy-the only way to ensure conservative values would be emphasized.

\footnotetext{
${ }^{33}$ Doern and Toner, The Politics of Energy, 67.

${ }^{34}$ Ibid., 69.

${ }^{35}$ Richards and Pratt, Prairie Capitalism, 66.

${ }^{36}$ Wesley, Code Politics, 92-93; Dyck, Provincial Politics in Canada, 542-543.

${ }^{37}$ Dyck, Provincial Politics in Canada, 544.

${ }^{38}$ Ibid.
} 
The provincial government of Alberta litigated or intervened on several cases in an effort to protect its jurisdiction. In 1977, Alberta, Manitoba and Quebec intervened on behalf of the government of Saskatchewan in CIGOL v. Saskatchewan, with the federal government intervening on behalf of CIGOL. The issue was whether a "royalty surcharge" imposed on oil companies drilling on provincial crown lands constituted a royalty-profits derived from the government's ownership of the resource-or a tax, which only the federal government has the authority to levy. ${ }^{39}$ The case was therefore significant in that it had the effect to interfere with both the provinces' jurisdictional capacity, but their ability to raise revenue as well. Ultimately, the Supreme Court of Canada found that the royalty surcharge constituted indirect taxation, and the impugned legislation was therefore ultra vires. ${ }^{40}$ For Premier Allan Blakeney of Saskatchewan, this case was further evidence of systematic discrimination against the west. Other commodities faced the same price increases as oil did, and yet only oil was being targeted for revenue by the federal government. ${ }^{41}$ Blakeney was not a conservative-indeed, he led a New Democratic government. Yet interference from the federal government such as this hindered his province's ability to introduce the sort of progressive legislation he desired. ${ }^{42}$ The same principle held true for Alberta: as long as the federal government interfered-and especially with the Trudeau Liberals in power-it would be difficult to implement policies with the values of western conservatism.

In 1978, another energy-constitutional case was brought forward, again involving the Government of Saskatchewan, and again with Alberta, Manitoba and Quebec plus New Brunswick and Newfoundland intervening. Central Canada Potash v. Saskatchewan depended on whether the Government of Saskatchewan was engaged in price fixing, or attempting to conserve potash as a natural resource by limiting supply. ${ }^{43}$ The case overturned an earlier precedent in Alberta, Spooner Oils Ltd. v. Turner Valley Gas Conservation which established the authority of the provinces to regulate the conservation of their natural resources. Despite not having any potash, this case was therefore relevant to each of the western provinces. As noted earlier, oil and natural gas in particular are resources necessitating government regulation in order to maintain the resources over the long term. Central Canada Potash was important for all western provinces for much the same reason as CIGOL v. Saskatchewan: victory for the federal government ran the risk of privileging Central Canadian interests, policies, and ideology above those in the West. These fears were ultimately realized with the

\footnotetext{
${ }^{39}$ William D. Moull, "Natural Resources: The Other Crisis in Canadian Federalism," Osgoode Hall Law Journal 18 (March 1980): 1-48.

${ }^{40}$ Ibid.

${ }^{41}$ Allan Blakeney, An Honourable Calling: Political Memoirs (Toronto: University of Toronto Press, 2008 ), 132.

42 Janet L. Hiebert, "Compromise and the Notwithstanding Clause: Why the Dominant Narrative Distorts our Understanding," in Contested Constitutionalism: Reflections on the Canadian Charter of Rights and Freedoms, ed. James B. Kelly and Christopher P. Manfredi (Vancouver: UBC Press, 2009), 113.

${ }^{43}$ Moull, "Natural Resources."
} 
implementation of the National Energy Program by the government of Pierre Trudeau in 1980.

\section{Exploited Again?}

The National Energy Program (NEP) was the single most important act in solidifying a relationship between provincial rights and conservatism in the second half of the west's history. The NEP, without input from the provincial governments, imposed a new pricing structure for Canadian oil and gas, and at a lower level than Alberta would have liked. ${ }^{44}$ The NEP also included a new energy sharing model where the federal government would take a substantially larger share of revenue by implementing additional taxes on the industry. ${ }^{45}$ One tax in particular, an export tax on natural gas, was a notable example. The federal government was aware the governments of Alberta and British Columbia in particular opposed such a tax, and yet proceeded with it regardless. ${ }^{46}$ In retaliation, the Government of Alberta proposed a reference question to the Alberta Court of Appeal asking whether a tax on natural gas owned solely by the provincial government was within the constitutional powers of the federal government. Section 125 of the British North America Act, 1867 prohibited one level of government from imposing taxes on another. The Court ultimately determined that such a tax would be ultra vires. ${ }^{47}$ This hypothetical scenario gave the provincial government more bargaining power, and in 1981 the federal and provincial governments reached a new agreement-though not one constituting a clear victory for either side. ${ }^{48}$

Nonetheless, by all appearances in the west, the federal government was again exploiting the west in the name of eastern interests. As Pratt observes, the conclusion was again "that central Canadians continue to regard the west as little more than a resource-rich hinterland, and Alberta in particular as a storehouse of energy resources which are too important to be left under provincial jurisdiction" ${ }^{49}$ However, this time around a substantial difference existed: during this period conservatives dominated Alberta provincially and in Alberta's federal seats. Roger Gibbins therefore suspects that "the cutting edge of western alienation may have been a purely partisan dislike; western Canadians were alienated as much because they were Conservatives as because they were western Canadians." 50 Aside from the ideological foundations we established earlier for strong provincial government being amenable to conservatism, we cannot discount the notion of an "us" versus "them" mentality playing a role along ideological lines.

\footnotetext{
${ }^{44}$ Dyck, Provincial Politics in Canada, 545.

${ }^{45}$ Doern and Toner, The Politics of Energy, 7-8.

${ }^{46}$ Troy Riddell and F. L. Morton, "Government Use of Strategic Litigation: The Alberta Exported Gas Tax

Reference," The American Review of Canadian Studies 34(3) (Fall 2004): 489.

${ }^{47}$ Ibid., 491.

${ }^{48}$ Ibid., 491-492.

${ }^{49}$ Larry Pratt, "Energy, Regionalism and Canadian Nationalism," Newfoundland Studies 1(2) (1985): 178.

${ }^{50}$ Gibbins, Prairie Politics and Society, 183.
} 
Indeed, the strongest and most prolific federal-provincial conflicts occurred during this period, when there was a mismatch between the dominant ideological faction in Alberta and in Ottawa. Natural resources aside, negotiations over constitutional amendment provoked further conflict. Gibbins suggests the process of constitutional negotiation severely undermined the fabric of the country. ${ }^{51}$ Not only was the new constitution viewed as the product solely of the federal Liberal government, but because there were no seats held by Liberals in Western Canada in Parliament, it was a process the west was altogether excluded from. Moreover, the new constitution did nothing to address the institutional problems of regional conflict in Canada. Not only was the process viewed as being contrary to western interests, but the end result as well. The amending formula was a success for strong provinces in one significant regard: it solidifies the claim that the provinces have a role to play in setting the national agenda, and establishes the equality of the provinces; i.e. Quebec is not treated differently. ${ }^{52}$ The dominance of provincial government is a mixed blessing for western conservatives, however. The provincial government is more likely to be ideologically favourable for them, but the strength of provinces in the amending formula comes at the expense of the very conservative principles prominent in the west. The constitution leaves no room for populism or individualism, whether in the way of constitutional referenda or another method of direct involvement with the amending process.

\section{Provincial Goes Federal}

We have now seen that a pattern of exploitation by the federal government, whether in perception or in practice, strengthened the link between strong provincial rights and conservatism in at least two ways. First, strong provincial rights aligned with the values of western conservatism, namely populism, liberalism and capitalism by allowing the provincial governments to pursue policies aligning with these values. Second, antagonism between bigL Liberals federally and big and small-c conservatives in the west added an "us" versus "them" dimension to federal-provincial disputes in the latter period. As we shall now see, provincial rights have continued to be pursued by conservatives outside of provincial government-that is, when jurisdictional gains impose no immediate benefit in a power sense-since the end of the constitutional debates suggests that these earlier events have crystallized the notion of provincialism as part of the western conservative ideology.

Preston Manning's Reform Party continued to advocate for many of the positions that had been relegated from the 1982 constitution negotiations and from the later Meech Lake and Charlottetown Accords. Brian Mulroney's Progressive Conservative government was

\footnotetext{
${ }^{51}$ Roger Gibbins, "Constitutional Politics and the West," in And No One Cheered: Federalism, Democracy and the Constitution Act, ed. Keith Banting and Richard Simeon (Toronto: Methuen, 1983).

${ }^{52}$ Ibid., 127.
} 
perceived to be favouring the conservative voters of other regions and Quebec in particular..$^{53}$ This left an opportunity for a party espousing the ideas of western conservatism to emerge. Although Manning sought to establish a party of the West rather than a party of ideology, the values and policies of the party clearly align with those we have found to be western conservative here: populism, liberalism and capitalism. ${ }^{54}$

Importantly for our purposes, though, the Reform Party continued to advocate for decentralization. ${ }^{55}$ Reform, unlike the Progressive Conservative government of Peter Lougheed or even the UFA and Social Credit parties before them, contested only at the federal level. Their advocacy for decentralization conferred no direct benefit in terms of the expansion of their powers. In fact, had the Reform Party proved electorally successful and had the opportunity to form government, this advocacy would have taken powers away from the party. This suggests that there was some degree of staying power for provincial rights within conservatism. Even the explanation that decentralization was advocated solely for electoral benefit seems inadequate-other conservatives, we shall now see, advocated for decentralization even when there was no tangible benefit to them.

David Rovinsky authored a paper in 1998 titled "The Ascendancy of Western Canada in Canadian Policymaking". Rovinsky describes how Western Canada "has always presented a distinctive regional viewpoint on national issues." 56 What he describes is essentially what we have identified here as western conservatism. Notably, Rovinsky also mentions several of the figures who would later go on to write the infamous "Firewall Letter" as leading figures in the ascendency of this school of thought. The Firewall Letter itself is notable for advocating for decentralization by way of encouraging then-Alberta Premier Ralph Klein to use the full extent of the province's existing constitutional powers. ${ }^{57}$ Taken together, these documents suggest there has been a high degree of continuity between western conservative thought as it has advanced forward, and support for decentralization and strong provinces as well. Unlike provincial governments and even the Reform Party, the authors of the Firewall Letter did not directly benefit from advocating this position. The authors do, however, advocate for using expanded provincial jurisdiction for conservative policy ends, explicitly noting "individual freedom" and "greater use of the referendum and initiative". This further bolsters the conclusion that, through the actions of the conflicts of the 20th century between the provincial and federal governments, a connection has developed between decentralization and the brand of conservatism in the west.

\footnotetext{
53 Tom Flanagan, Waiting for the Wave: The Reform Party and the Conservative Movement, second edition (Montreal \& Kingston: McGill-Queen's University Press, 2009), 51.

${ }^{54}$ Ibid., 53-56.

${ }^{55}$ Laycock, "Making Sense of Reform," 132-133.

${ }^{56}$ David Rovinsky, “The Ascendancy of Western Canada in Canadian Policymaking," Policy Papers on the Americas IX Study 2 (February 16 1998): 14

${ }^{57}$ Stephen Harper et al., [Firewall Letter] “An open letter to Ralph Klein,” National Post, January 24, 2001.
} 
Rovinsky's paper is interesting for another reason. The notion of the "ascendancy of Western Canada" effectively predicts the rise of western conservatism nationally that occurred in the 21st century under the banner of the united Conservative Party, led by Stephen Harper-the very same Firewall author. Brooke Jeffrey suggests the present-day Conservative Party has advanced a significantly more decentralized view of Canadian federalism than their Liberal predecessors, and even more than the former Progressive Conservative Party. ${ }^{58}$ Jeffrey argues that Harper seeks to promote a "neo-liberal agenda". She compares Harper's views on decentralization to the states' rights movement in the United States, citing figures such as Ronald Reagan as evidence of similarities. ${ }^{59}$ Given the history we have now demonstrated that has linked western conservatism with provincial rights, we can reach a different conclusion: Harper's agenda is the ascendency of Western Canadian conservatism as it has been articulated in this paper. Given the united Conservative Party must campaign to a national electorate, it is undoubtedly tempered with other branches of Canadian conservatism, but Harper's views on federalism are in line with a long tradition of Western Canadian political thought. In this sense, Jeffrey is correct in assuming Harper's views are American in origin-what she misses is that the Americans in question started out as migrants to western Canada, bringing the values of populism, liberalism and capitalism with them.

\section{Conclusion}

The question we began this paper with was whether there was an ideological link between conservatism and a decentralized federation in Canada. To answer this question, we considered the sources the desire for decentralization itself, finding it to be a result of the early (and ongoing) policies of the federal government with regard to the west. We also identified the origin of Western Canadian conservatism, finding it to be based largely on American rather than tory influences of Central Canada, and moreover centred primarily in Alberta. In origin, then, decentralization and conservatism do not form an ideological unit. But, because of the continued policy choices of the federal government vis-à-vis the west, decentralization presented an opportunity for realizing the policy preferences of conservatives, particularly once Alberta's economy shifted from primarily agriculture to primarily energy based. Furthermore, the ideological divisions between the federal and provincial government of Alberta in this era created an "us" versus "them" mentalitytogether, these factors cemented a relationship between western conservatism and decentralization, which continues to subsist today.

Whether decentralization is an ideological feature of conservatism, then, depends on one's meaning. The pattern of affinity between them could be considered ideological in that

\footnotetext{
${ }^{58}$ Jeffrey, "Prime Minister Harper's Open Federalism."

${ }^{59}$ Ibid., 120.
} 
provincial rights continue to be asserted alongside other conservative values. On the other hand, decentralization could be considered a means to an end for implementing these other values. Considering the longevity of their relationship, we can perhaps tentatively conclude the former. Future research might examine whether this link persists in the future: the heartland of western conservatism, Alberta, is now governed by the New Democrats, and the Conservative Party has recently lost power to the Liberal Party federally. How conservatives react to these changes will give us an indication of whether the relationship between decentralization and conservatism is as solid as it has appeared. 


\section{Bibliography}

Banack, Clark. "American Protestantism and the Roots of 'Populist Conservatism' in Alberta." In Conservatism in Canada, edited by James Farney and David Rayside, 231248. Toronto: University of Toronto Press, 2013.

Bernier, Maxime. "Ottawa should quit intruding on provincial jurisdiction." National Post, October 13, 2010. Accessed September 20, 2015. http://news.nationalpost.com/fullcomment/maxime-bernier-ottawa-should-quit-intruding-on-provincial-jurisdiction.

Blakeney, Allan. An Honourable Calling: Political Memoirs. Toronto: University of Toronto Press, 2008.

Cairns, Robert D. "Natural Resources and Canadian Federalism: Recurring Conflict, and Resolution." Publius: The Journal of Federalism 22 (Winter 1992): 55-70.

Cooper, Barry. It's the Regime, Stupid!: A Report from the Cowboy West on Why Stephen Harper Matters. Toronto: Key Porter, 2009.

Dacks, Gurston. "From Consensus to Competition: Social Democracy and Political Culture in Alberta." In Essays in Honour of Grant Notley: Socialism and Democracy in Alberta, edited by Larry Pratt. Edmonton: NeWest Press, 1986.

Doern, G. Bruce and Glen Toner. The Politics of Energy: The Development and Implementation of the NEP. Toronto: Methuen, 1985.

Dyck, Rand. Provincial Politics in Canada: Towards the Turn of the Century. Scarborough: Prentice Hall, 1996.

Elton, David K. "Alberta and the Federal Government in Historical Perspective, 1905-1977." In Society and Politics in Alberta: Research Papers, edited by Carlo Caldarola, 108130. Toronto: Methuen, 1979.

Flanagan, Tom. Waiting for the Wave: The Reform Party and the Conservative Movement, Second Edition. Montreal \& Kingston: McGill-Queen's University Press, 2009.

Gibbins, Roger. Prairie Politics and Society: Regionalism in Decline. Toronto: Butterworths, 1980.

Gibbins, Roger. "Constitutional Politics and the West." In And No One Cheered: Federalism, Democracy and the Constitution Act, edited by Keith Banting and Richard Simeon. Toronto: Methuen, 1983.

Gibbins, Roger and Loleen Berdahl. Western Visions, Western Future: Perspectives on the West in Canada, second edition. Peterborough: Broadview, 2003.

Harper, Stephen, Tom Flanagan, Ted Morton, Rainer Knopff, Andrew Crooks and Ken Brossenkool. 2001. [Firewall Letter] "An open letter to Ralph Klein.” National Post, January 24.

Hiebert, Janet L. "Compromise and the Notwithstanding Clause: Why the Dominant Narrative Distorts our Understanding." In Contested Constitutionalism: Reflections on the Canadian Charter of Rights and Freedoms, edited by James B. Kelly and Christopher P. Manfredi, 107-125. Vancouver: UBC Press, 2009.

Jeffrey, Brooke. "Prime Minister Harper's Open Federalism: Promoting a Neo-Liberal Agenda?" In The Case for Centralized Federalism, edited by Gord DiGiacomo and Maryantonett Flumian, 108-136. Ottawa: University of Ottawa Press, 2010. 
Laycock, David. "Making Sense of Reform as a Western Party." In Regionalism and Party Politics in Canada, edited by Lisa Young and Keith Archer, 129-157. Oxford: Oxford University Press, 2001.

Mallory, J. R. Social Credit and the Federal Power in Canada. Toronto: University of Toronto Press, 1954.

Moull, William D. "Natural Resources: The Other Crisis in Canadian Federalism." Osgoode Hall Law Journal 18 (March 1980): 1-48.

Noël, Alain. "Is Decentralization Conservative? Federalism and the Contemporary Debate on the Canadian Welfare State." In Stretching the Federation: The Art of the State in Canada, edited by Robert Young, 195-219. Kingston: Institute of Intergovernmental Relations, 1999.

Pratt, Larry. "Energy, Regionalism and Canadian Nationalism." Newfoundland Studies 1(2) (1985): 175-199.

Richards, John and Larry Pratt. Prairie Capitalism: Power and Influence in the New West. Toronto: McClelland and Stewart, 1979.

Riddell, Troy and F. L. Morton. "Government Use of Strategic Litigation: The Alberta Exported Gas Tax Reference." The American Review of Canadian Studies 34(3) (Fall 2004): 485-509.

Rovinsky, David. "The Ascendency of Western Canada in Canadian Policymaking." Policy Papers on the Americas IX Study 2 (February 16 1998).

Thrift, Gayle. "By the West, for the West': Frederick Haultain and the Struggle for Provincial Rights in Alberta." Alberta History 59 (Winter 2011): 2-11.

Wesley, Jared J. Code Politics: Campaigns and Cultures on the Canadian Prairies. Vancouver: UBC Press, 2011.

Wiseman, Nelson. "The Pattern of Prairie Politics." In Party Politics in Canada, edited by Hugh G. Thorburn and Alan Whitehorn, 351-368. Toronto: Prentice Hall, 2001.

Wiseman, Nelson. "Provincial Conservatism." In Conservatism in Canada, edited by James Farney and David Rayside, 209-230. Toronto: University of Toronto Press, 2013. 